\title{
Audience-Performer Interface as a Battlefield of Expression: A Study of Ateso Oral Narratives*
}

\author{
Simon Peter Ongodia \\ Makerere University, Kampala, Uganda
}

\begin{abstract}
The purpose of the study was to investigate and illustrate the challenges faced by performers and audiences during Ateso oral narratives in Ateso speaking communities in Uganda. The study used ethnographic and discurssive analyses methods of research. The topic was Audience-Performer Interface as a Battlefield of Expression: A Study of Ateso Oral Narratives. Ethnographic method of study was used in Ateso speaking communities of Serere, Ngora, Bukedea and Pallisa districts of Uganda. The author stayed with communities for four to seven days in 2009, 2010 and 2011. The study analysed the interpretational dimensions of the oral narrative episodes. Questionnaires and focused group discussions were used to solicit data from a total of 20 (33.3\%) out of 60 persons. The study saw that there was dire need to revive the cultural media of communication in Teso. In Serere, Bukedea and Ngora there was more of unpleasant intrusion than in Pallisa and Serere. Performers should consider their audiences complementary to the narration and establish rapport. Audiences should appreciate the efforts of the narrators to keep the cultural norm of story-telling alive in Teso. The Ministry of Education and Sports in Uganda should encourage local languages at all levels of education.
\end{abstract}

Keywords: Ateso, audience-performer interface, battlefield of expression, cultural media, Etesot, interpretational dimensions, Iteso, retrogressive, Teso, unpleasant intrusion

\section{Introduction}

The story teller is taking his or her audience for a ride: an examination of Ateso oral narratives in Uganda. The study investigated charged reactions between performers and their attendant audiences in some selected communities in Teso sub-region. The narrative dynamics of Iteso performers in oral narrations in selected Ateso speaking districts of Uganda were closely observed and some conclusions were arrived at. The reciprocal feedback from the reciepients of the narratives was also analysed

\section{Background}

In a narrative performance scenario it is assumed that the audience and performer interface is on terms of understanding the various productive and receptive roles of narrator and listener/observer. But, is this always the case? In the ethnographic study the author undertook in Ateso speaking communities of Serere, Ngora, Bukedea, and Pallisa districts of Uganda, there seemed to emerge antagonistic forces at play. Should some performers consider audience-performer interface an unpleasant intrusion for performance? In Ateso oral

* Acknowlegements: The study was carried out with the help of Carnegie Corporation NGAA (Next Generation of African Academics) small grants and Makerere University Directorate of Research and Graduate Training.

Simon Peter Ongodia, Lecturer, Ph.D. candidate, Department of Literature, Makerere University. 
narratives, like all folktale experiences, utterances and non-verbal protestations were exchanged between performer and audience. Yet, some of the incidents were deterrent to performance. This emerged as one of the findings of the Ph.D. research entitled "Performance of Ateso Oral Narratives".

The author examined the complex mutuality and the accompanying tides in the performances of Ateso oral narratives. As the author noted that whenever the performer's audience reacted with enthusiastic admiration, the artist held back his or her voice with detachment, until silence was restored. This might have been chiefly because the performer saw them as one carrying out the noble and elevated duty. They wanted to take no chances about the performance. It should not be corrupted by undue interruptions and what could turn out to be insincere applauses. The issues of the account should remain intact in his or her mind for a successful narrative that was expected of him or her to be realized. The intimacy that arose between performer and audience was analyzed to ascertain how it had a bearing on performance. As had been noted earlier, performers tried to establish good rapport with the audience in their various styles, and at times there was a blurring border created between the performer and the audience. Social intercourse inevitably erupted as the mutuality was established. There were times when roles were swapped between performer and audience with a lot of ease.

According to Boden and Zimmerman (1991), conversation analysis (akin to oral performances) arose from an ethno-methodology in which the crux of the matter was the primordial site of social order found in the members' use of practices to produce, make sense of, and thereby render accountable, features of their local circumstances according to their cultural and socio-economic circumstances. In this study, the author analyzed how texts were created, interpreted to be humorous or not according to the reactions from the audiences. The author was keen in noting the incidents and utterances that tickled audiences to laughter and those that moved them to remorsefulness and apathy.

The research also discusses the interpretational dimensions of the oral narrative episodes. The narrative did not express issues ignoring the tides. The study examined how the performers created scenes that were reading the signs of time. When the reciprocal utterances and silence from the audience became collaborative and accountable accomplishments, agency emerged not just as a metaphysical principle of a performer's illusion but as an essential feature of the organization of the social interaction. Performance was seen as integral to social and institutional organizations with mechanisms for the satiation of social and cultural quests and emulation of the lessons therein.

Narration is defined as a function or a set of introduction techniques combining the narrative, proper speaking, dialogue, monologue and free indirect style which creates fiction (Hamburger, 1993, pp. 68-71). In the Kate Hamburger theory, the performer is distinguished from the author of a tale, in this case the anonymous originator of the tale. The performer is not just a narrator but one who creates the fictional world and establishes a mutual connection with an audience. Every audience and every performer faces a dual experience of consciousness. The audience reacts to content and form on one hand, and on the message and medium the performer uses to transmit that communication on the other hand. While the performer is pre-occupied with creating atmosphere conducive for the narrative, the audience is sucked into events taking place in the tale and experiencing these events as form. As to which of the two paradigms (event and form) is a predominant variable left at an awareness and consciousness of the performer or individual members of the audience. This creates the audience-performer mutual interaction. The ability of the audience to make sense out of the oral narrative performance depends on its focus and interest in the same. The audience concentration is a function of expectations, personal experiences and orientations. Due to this mutual adherence, the determinant force of 
tradition directs individual behavior in the performance experience to overlook the quirk manipulations of traditions of performance. They see the performer as a person, an individual like one of them, but with a definite duty to carry out. In this mutuality, the description of collective, shared cultural practices and norms which determine the reciprocal behavior to be exhibited by both parties.

\section{Methods Used}

The objectives of this study are to illustrate the challenges faced by performers and audiences in narrativity of Ateso oral narratives in Ateso speaking communities in Uganda and Kenya. The research was carried out using the ethnographic and discurssive analyses methods of research. The author stayed with communities for an average of four days of their "festive/holiday periods" in November to January in 2009, August 2010 and December 2011. A total sample of 20 33.3\% interviewees was selected using purposive sampling from a population of about 60 members of audiences in the different performance sites. The study analysed the interpretational dimensions of the oral narrative episodes. It challenged the held assumption that reciprocal utterances and silence from the audience become collaborative and accountable accomplishments. The author used questionnaires and focused group discussions to solicit data. The author referred to some theories such as the diffusionism theory which asserts that cultural changes occur horizontally as results of mutual interactions of peoples, and then the author examined possible narrativity mutations in Ateso oral narratives.

\section{Results}

Using the quantitative data analysis techniques, the study received the following results. In 18 performances in 12 families and communities in the four districts of Serere, Ngora, Bukedea, and Pallisa in Uganda were observed and studied. Firstly, there was a high rate of audience antagonism in Bukedea and Ngora than in Pallisa and Serere. Overall rate of unpleasant intrusion was $75 \%$. Some of the incidents were deterrent to performance as was seen in Teso communities the author stayed with. It establishes the relationship in the interaction of audience-performer in line with Bavelas, Coates, and Johnson (2000) who say that listeners become co-narrators in a performance. Secondly, it established these psychological observations on mutuality and intimacy exhibited in socio-anthropological settings and identified these facets in the Teso socio-cultural setting. The study observed that in telling a story, a performer underwent various breath gaps, not only because he or she wanted to take a breath between one episode or subplot and the next, but also because some forces were at play, both verbal and non-verbal, as the narrative progressed. There were also other diversionary sights such as the stage hands or prompters who becomes unnecessarily noticed. Cultural changes and issues of identify were focal points in the discussions hence, a yearning for platform to address such issues.

\section{Conclusions}

Even when there is a happy cultural correspondence between performance and audience and the roles on all sides are adhered to, there is no guarantee that a performer's meanings were understood as he or she had intended. Carlson (1989) talked of audiences “reading” a performance and used Eco's semiotic perspective of reader (audience) response, which involved the ideas of "model reader" and "open” and "closed" texts. The study was able to deal interpretatively with the expressions in the same way as the author deals generatively with them. Closed performances aimed at generating a precise response from a more or less precise group of audience, whereas open performances gave fewer and fewer specific response indications and were 
increasingly open. Paradoxically, open performances where all were invited free of charge were often less accessible than closed ones. It is in this generation and interpretation of meaning that the interplay of space and utterance was observed, and as Carlson stated: "stage utterances can shape the way we perceive the context [space] of their occurrence. In its turn, context lends meaning or may modify meaning considerably” (Carlson, 1989, p. 187). For example, in the tale of Epolon ka Aberuke (The old Man and his Wife), the plight of the pumpkins-cum-sisters given by divine providence to the barren couple could be understood in the contexts of their speeches and gave their discourse a tragicomic flavour. Ungrateful, human beings should not own what they do not appreciate. The audience saw the connections in the parameters and the author recalled the sophisticated contract between performer and audience as the generator of that meaning. There was effective use of space in relations to the semantics of the performance. When the audience frowned at the misadventures of the characters in the narrative, it stood as the agreed norm. When it appreciated the amusement with smiles and laughter, those aspects of response to performance defined the occasion. It was an audience's laughter which defined the joke, and at the same time, failure to laugh could determine the level of irony in the comic performance (Carlson, 1989, p. 47) or simply insensitivity to the comic aspects of Ateso oral narratives. In the analysis, such dynamics had to be commutative if a performance was to work out as a performance. In effect both organisational and cognitive principles had to be at work in the Teso cultural context as well as a conscious mutual interaction between the performer and his or her audience.

Atkinson \& Heritage (1984) argued that the many difficulties of speech act theory ultimately derive meaning from the failure of its proponents to grasp that utterances are in the first instance contextually understood by reference to their placement and participation within sequences of actions. So, in oral performance, the illocutionary force of talk which a performer tries to establish in the performer-audience mutual interaction is determined not in isolation but by reference to what a particular event accomplishes in a sequence of prior and following utterances, or what Heritage calls "the architecture of inter-subjectivity" (Heritage, 1984, p. 254).

As mentioned earlier on in the study, the author noted that difficulties pointed out in the speech act theory eventually boil down to inability of its proponents to comprehend that actions and utterances were primarily contextually understood by reference to their placement and participation within the season and series of activities. That was why the illocutionary force of performances was examined not in isolation but by reference to what the particular trend gained in respect to earlier and ensuing actions and utterances. The findings suggested that sequences might be extended to illuminate the gist of the narratives, hence the context-oriented and the content-trend. The research proceeded to analyse with some assurance that interface understandings were shown at performer-audience mutual interaction.

Firstly, the feud established a new relationship in the interaction of audience-performer in line with Bavelas, Coates, and Johnson (2000) who say that listeners become co-narrators in a performance; secondly, it established these psychological observations on mutuality and intimacy exhibited in socio-anthropological settings; thirdly, just as Carlson (1989) talked of audiences “reading” a performance and used Eco's semiotic perspective of reader (audience) response, Ateso audiences were able to deal interpretatively with performers' expressions; fourthly, some of the incidents were deterrent to performance; However, fifthly, in Ateso narrations, moments of unpleasant and at times bitter exchanges between the audience and the performers were provoked by inconsistencies in plotting, characterization and spectacle; sixthly, some performers were able to 
extricate themselves from the illusionary world in order to scold a wayward member of the audience; And seventhly, following the diffusionism theory that cultural changes occur horizontally as results of mutual interactions of peoples, the study delved into the mutations. The traditional folktale narrative styles and diction were mutating and the tales did not start with the old "Long, long time ago... " adage.

In the incidence where the narrator, Amojong Ibalasa, paused in order to reprimand part of the audience the performer extricated herself from the world of illusion and became her real self: an old Atesot who deserved respect and reverend attention from her ungrateful (if not disrespectful) audience. She could not let those ill-mannered "wiseacres" to spoil the authority she had established in the narrative. This performance being a cultural activity inherently gave her authority to be listened to and respected. After the exchange, it had not been smooth for her to resume her role in the illusionary engagement. During the exchange, there was a strange feeling that not all was well. The author also felt uneasy as a researcher. It should not come to this temperamental exchange especially since there had been very few people willing to perform the oral narratives in the first place. Now that the football star was making "blunders" in the spot kicks in the field, the crippled members of spectators were giving advice on how they could not have missed the goal had they been the ones playing. But did it warrant vehement defence from the artist either? Perhaps not. This was what Balls (1998) called a bizarre moment when he described a similar incident when a proficient actor Nichol Williams in the performance of Shakespeare's Macbeth (1998) at Stratford broke the spell of illusion in order to scold the notorious belching member of the audience. The performer had been about to recite the famous soliloquy when the unfortunate belching intruded into the path.

Balls (1998) reports:

I once saw Nichol Williamson play Macbeth at Stratford. During the floating dagger scene, when all was hushed in anticipation of the soliloquy, someone belched. Though the audience controlled itself, Williamson didn't. Sitting down on a stool, he began to lecture the audience about how he was not going to be distracted from delivering one of the greatest speeches in English drama. It was a bizarre moment, because he'd broken the spell, making you want to pinch yourself, to check that it was really happening. (p. 35)

Amojong Ibalasa who interrupted her tale to admonish the unruly section of the audience could not pretend to continue with the narration as if nothing was wrong. She descended from the illusionary platform and resumed her social and cultural position as an elderly Atesot who had to be given utmost respect and attention. It was her duty to remind the wayward section of the audience the traditional norms of respect for elders especially those performing cultural social duties like story telling. The author could not hide a smile of approval. True; the performer-audience interaction during performance ought to be mutual, but it has to be regulated in order for sanity to reign in the experience.

\section{Recommendations}

Performers should not consider their audiences as stumbling blocks but rather as complementary to the narration. Firstly, they ought to strive to establish rapport for effective communication; secondly, audiences should appreciate the efforts of the rather few narrators to keep the cultural norm of story-telling alive in Teso; thirdly, the Ministry of Education and Sports should lay emphasis on studying local languages right from the lower levels of Primary to Secondary and Universities rather than planning to retrogressively abolish them; fourthly, knowledge received from oral narratives should be used in Tesoland for development and growth; 
fifthly, promotion of Ateso oral narratives and their study will help the Ateso speaking communities to rediscover value in their traditional inheritance; and sixthly, the issue of lack of literature in Ateso will be addressed.

\section{References}

Atkinson, J. M., \& Heritage, J. (Eds.). (1984). Structures of social action: Studies in conversation analysis. Cambridge: Cambridge University Press.

Balls, E. (1998). Slaves in the family. New York: Farrar, Straus \& Giroux.

Barthes, R. (1997). Introduction to the structural analysis of narratives. Image - Music - Text. London: Fontana.

Bavelas, J. B., Coates, L., \& Johnson, T. (2000). Listeners as co-narrators. Journal of Personality and Social Psychology, 79(6), 941-952.

Boden, D., \& Zimmerman, D. H. (Eds.). (1991). Talk and social structure: Studies in ethnomethodology and conversational analysis. Oakland: University of California Press.

Carlson, M. (1989). Theatre Audiences and the Reading of Performance. In T. Postlewait, \& B. A. McConachie (Eds.), Interpreting the Theatrical Past (p. 47). Iowa City: University of Iowa Press.

Hamburger, K. (1993). (1957). The logic of literature. (M. J. Rose, Trans.). Bloomington \& Indianapolis: Indiana University Press.

Heritage, J. (1984). Garfinkel and ethnomethodology. Cambridge: Polity Press.

Mushengyezi, A. (2007). From orality of literary: Translating traditional Ugandan oral forms in texts for children (Ph.D. Dissertation, The University of Connecticut).

Ryan, M. L. (2004). Narrative across media. Lincoln, London: University of Nebraska Press.

Samuel, D. (1999). Memory. London: Phoenix. 